\title{
STRUKTUR SEMANTIS VERBA PSIKOLOGI BAHASA MANDAILING
}

The Semantic Structure of Mandailing Psychological Verb

\author{
Pengabdi Daulay dan Mulyadi \\ Fakultas Ilmu Budaya, Universitas Sumatera Utara \\ Jalan Universitas No. 19 Padang Bulan, Medan, Indonesia \\ Pos-el: abdimumtaz93@gmail.com;mulyadi.usu@gmail.com
}

\begin{abstract}
Abstrak
Penelitian ini mendeskripsikan struktur semantis predikat mental BM pada subkategori verba sebagai subjek pengalam dan verba sebagai objek pengalam. Adapun yang melatar belakangi penulisan ini mengingat bahwa predikat mental atau verba psikologi termasuk verba yang memiliki pemetaan komponen semantis yang sangat rumit dan membutuhkan strategi yang tepat untuk menghindari kekeliruan dalam membatasi makna butir leksikal yang dianalisis. Penelitian ini menggunakan metode deskriptif kualitatif. Data penelitian berupa verba mental yang bersumber dari Bahasa Mandailing (BM). Kemudian data dianalisis dengan menggunakan teknik prafrase untuk mengidentifikasi butir-butir leksikal yang secara intuitif termasuk predikat mental. Hasil penelitian menunjukkan bahwa makna verba kognisi 'malamun' dan 'mangangankon dibentuk dari MEMIKIRKAN berpolisemi MENGATAKAN dan MEMIKIRKAN berpolisemi TERJADI, makna verba pengetahuan 'mamboto' dan 'ingot' dibentuk dari MENGETAHUI berpolisemi MENGATAKAN, makna verba emosi 'mabiar' dan 'manyolop' dibentuk dari MERASAKAN berpolisemi MEMIKIRKAN, makna verba persepsi 'manyirik' dan 'manatap' dibentuk dari MELIHAT berpolisemi MERASAKAN, MELIHAT berpolisemi MENGATAKAN.

Kata-kata kunci: Struktur, Semantis, Verba, Psikologi, Mandailing
\end{abstract}

\section{Abstract}

This study describes the semantic structure of BM's mental predicate in the verb subcategory as the subject of experience and the verb as object of experience. As for the background of this writing, remember that the mental predicate or psychological verb includes a verb that has a very complicated semantic component mapping and requires the right strategy to avoid mistakes in limiting the meaning of the lexical items being analyzed. This study used descriptive qualitative method. Research data in the form of mental verbs sourced from Mandailing Language (BM). Then the data are analyzed using prefreshation techniques to identify lexical items that intuitively include mental predicate. The results showed that the mean of cognition verbs 'malamun' and 'mangangankon' was formed from THINKING the polishemic TELLING and THINKING the polishemic HAPPENING, the meaning of knowledge verb 'mamboto' and 'ingot' was formed from KNOWING the polishemic TELLING, the meaning emotion verb 'mabiar' an 'manyolop' was formed from FEELING polishemic THINKING, the meaning of perception verb 'manyirik' and 'manatap' was formed from SEEING the polishemis FEELING, SEEING the polishemic TELLING Keywords: Structure, Semantics, Verbs, Psychology, Mandailing.

\section{PENDAHULUAN}


Verba psikologi dipahami sebagai kata kerja yang menggambarkan emosi dan melibatkan kondisi mental pada argumen pengalam. Dalam penelitian linguistik, verba psikologi sangat penting baik dari perspektif teoretis dan kognitif. Berbeda dengan verba transitif seperti membunuh atau menulis, verba psikologi tidak menetapkan agen peran tematik dan pasien, tetapi lebih tepatnya mengekspresikan keadaan psikologis dan mengambil pengalam sebagai salah satu argumennya (Droge, 2014: 149).

Dalam interpretasi yang lebih luas verba psikologis meliputi verba persepsi (mendengar, melihat dan merasa); verba kognisi (berfikir, mempercayai dan merenung); verba evaluasi (memperkirakan, menghargai dan menilai). Begitu juga halnya dengan verba emosi (gembira, bangga, terharu dan dendam) disetarakan dengan verba psikologis (Kitis, 2008: 3-4 dalam Mulyadi).

Penelitian yang berkaitan dengan verba psikologis telah banyak dilakukan oleh penelitipeneliti terdahulu. Ciluentes (2015) dalam penelitiannya mengemukakan bahwa dalam bahasa spanyol pergantian transitif atau intransitif pada kelas verba psikologis ditentukan oleh tingkat keaktifan subjek, aspek predikat dan unsur elemen kontruksinya. Begitu juga Ena (2016) berpendapat bahwa produktivitas kontruksi verba psikologis tidak terbatas pada verba pengalam, tetapi dibuktikan dengan verba yang lebih mudah penggunaan verba psikologisnya yang tidak memungkinkan dibantah dengan analisis structural yang 192 memperlakukannya secara khusus dan dikaitkan dengan sintaksis, aspek dan struktur tematik.

Begitu juga pada penelitian yang dilakukan oleh Widani (2016) beliau mengatakan bahwa verba "mengambil" dalam bahasa Bali dapat diekspresikan dalam beberapa leksikon, yaitu: "nyemak/ngambil, nyuang, nyurud, nuduk, ngalap, nimba, ngotèk, nyèndok, ngarebut, nyopèt, ngarampok, nyambrèt, ngamaling dan ngutil/ngalamit".

Berdasarkan pandangan- pandangan di atas, kajian ini dilakukan dengan mendasarkan pemahaman pada asumsi bahwa BM memiliki verba psikologi yang juga dimiliki oleh bahasabahasa yang lain karena verba merupakan ciri keuniversalan bahasa-bahasa di dunia. Kajian ini membutuhkan pemecahan berdasarkan teori semantik yang relevan dengan perilaku verbanya. Dengan demikian konsep teoritis yang dijadikan sebagai acuan utama adalah konsep teori Metabahasa Semantik Alami (MSA). Teori ini dikembangkan oleh Wierzbicka (1996) yang dirancang untuk mengeksplikasikan semua makna, baik makna leksikal, makna gramatikal, maupun makna ilokusi. Asumsi dasar teori MSA menyatakan bahwa analisis makna akan menjadi lebih sederhana dan tuntas. Akan tetapi, agar analisis makna sederhana dan tuntas, digunakan perangkat makna asali (semantic primitives) sebagai elemen akhir dalam analisis makna.

Pada penelitian ini verba psikologi (keadaan) dipilih sebagai isu masalah yang harus dituntaskan dengan menyajikan bukti-bukti yang bersumber dari BM. Adapun verba psikologi yang dimaksud adalah verba kognisi (melamun 
'malamun', mengangankan 'mangangankon'), verba pengetahuan (mengetahui 'mamboto', mengingat 'ingot'), verba emosi (takut 'mabiar', marah 'manyolop'), verba persepsi (melirik 'manyirik' menatap 'manatap'). Pemilihan BM sebagai objek dalam penelitian ini memiliki alasan tertentu, sekalipun BM secara geografis memiliki wilayah tutur yang sangat luas, namun sejauh ini BM telah banyak mengadopsi kosakata dari BI. Fakta ini dapat dilihat pada percakapan sehari-hari penutur asli BM yang banyak menggunakan kata-kata pinjaman dari BI. Hal ini merupakan kurangnya perhatian pemerintah setempat kepada BM tampak pada kurangnya penggunaan BM dalam pelajaran muatan lokal di sekolah-sekolah.

\section{LANDASAN TEORI}

Pada penelitian ini, konsep yang dibatasi adalah perbedaan jenis-jenis verba psikologi: verba sebagai subjek pengalam dan verba sebagai objek pengalam. Verba psikologi adalah kata kerja yang menggambarkan emosi dan melibatkan mental pada argumen pengalam. Yang menjadi ciri utama dari verba psikologi ini adalah kata kerja statif yang mengekspresikan keadaan psikologis dan menetapkan peran pengalamnya (dari keadaan psikologis) ke salah satu argumennya (Droge. 2014: 152). Ringkasnya, pengalam adalah argumen yang mengalami keadaan mental tertentu yang ditunjukkan oleh predikatnya (Broukhuis, 2008: $1)$.

Kajian ini menggunakan teori Metabahasa Semantik Alami (MSA). Teori
MSA merupakan kajian semantik leksikal. Asumsi dasar teori ini adalah bahwa makna kompleks dapat dideskripsikan dengan menggunakan konfigurasi elemen makna yang lebih sederhana hingga tidak dapat dapat diuraikan lagi. Teori MSA memiliki prinsip dasar untuk menghindari terjadinya kekaburan dan keberputaran dalam analisisis makna.

Ada tiga konsep teoritis dalam teori MSA yaitu makna asali (semantic primitive), polisemi non-komposisi (non-compositional polysemy) dan sintaksis universal (universal syntax).

\section{Makna asali}

Analisis makna akan tuntas jika menggunakan perangkat yang disebut makna asali. Makna asali adalah makna yang tidak berubah dan telah diwarisi manusia sejak lahir, atau dengan kata lain makna pertama dari sebuah kata yang tidak mudah berubah meskipun terjadi perubahan kebudayaan (perubahan zaman). Makna asali merupakan refleksi dan pembentukan pikiran yang dapat dieksflikasi dari bahasa alamiah yang merupakan satusatunya cara dalam mempersentasikan makna (Wierzbicka, 1996: 31).

Eksplikasi makna tersebut harus meliputi makna kata-kata yang secara intuitif berhubungan atau sekurang-kurangnya memiliki medan makna yang sama. Seperangkat makna asali sebagai parameter umum (common measure) untuk meneliti perbedaan semantis antarbahasa. Makna sebuah kata merupakan konfigurasi makna asali dan bukan ditentukan oleh makna kata yang lain dalam leksikon. 
Pengeksplikasian makna asali dilakukan dengan parafrase dengan menggunakan bahasa alamiah (ordinary language), dan bukan menggunakan bahasa yang bersifat teknis (Wierzbicka, 1996:31). Implikasi teoretis dari keberadaan makna asali adalah untuk menerangkan seluruh makna kompleks apa pun dengan cara yang lebih sederhana. Hal ini disebabkan makna asali mengandung keteraturan. Bertolak dari keteraturan makna inilah akhirnya berkembang makna lain yang lebih kompleks yang kemudian cenderung memperlihatkan ketidakteraturan. Selanjutnya, apabila seluruh leksikon dianalisis secara mendalam, diasumsikan bahwa fitur yang teratur itu dapat ditemukan. Hal ini mengisyaratkan bahwa sejauh mana pun perkembangan dan perubahan makna pada dasarnya dapat ditentukan. Tentu saja dengan syarat makna asalinya dapat dideskripsikan.

Dalam teori MSA, eksponen makna asali bersumber dari bahasa inggris. Sekalipun demikian, eksponennya dapat dipadankan dengan bahasa-bahasa lain, termasuk bahasa Indonesia. Adapun versi bahasa Indonesianya dapat diterjemahkan pada tabel berikut ini:

\begin{tabular}{|l|l|}
\hline Komponen & Elemen Makna Asali \\
\hline Substantif & $\begin{array}{l}\text { AKU, KAMU, } \\
\text { SESEORANG/ORANG, } \\
\text { SESUATU/ HAL, } \\
\text { TUBUH }\end{array}$ \\
\hline $\begin{array}{l}\text { Substantif } \\
\text { relasional }\end{array}$ & JENIS, BAGIAN \\
\hline Pewatas & INI, SAMA, LAIN \\
\hline
\end{tabular}

\begin{tabular}{|c|c|}
\hline Penjumlah & $\begin{array}{l}\text { SATU, DUA, SEMUA, } \\
\text { BANYAK, BEBERAPA }\end{array}$ \\
\hline Evaluator & BAIK, BURUK \\
\hline Deskriptor & BESAR, KECIL \\
\hline Predikat mental & $\begin{array}{l}\text { PIKIR, TAHU, INGIN, } \\
\text { RASA, LIHAT, } \\
\text { DENGAR }\end{array}$ \\
\hline Ujaran & UJAR, KATA, BENAR \\
\hline $\begin{array}{l}\text { Tindakan, } \\
\text { peristiwa, } \\
\text { gerakan, } \\
\text { perkenaan }\end{array}$ & $\begin{array}{l}\text { LAKU, TERJADI, } \\
\text { GERAK, SENTUH }\end{array}$ \\
\hline $\begin{array}{l}\text { Keberadaan dan } \\
\text { milik }\end{array}$ & ADA, PUNYA \\
\hline Hidup dan mati & HIDUP, MATI \\
\hline Waktu & $\begin{array}{l}\text { BILA/WAKTU, } \\
\text { SEKARANG, } \\
\text { SEBELUM, SETELAH, } \\
\text { LAMA, SEKEJAP, } \\
\text { SEBENTAR, } \\
\text { SEKARANG, SAAT }\end{array}$ \\
\hline Ruang & $\begin{array}{l}\text { (DI) MANA/TEMPAT, } \\
\text { (DI) SINI, (DI) ATAS, } \\
\text { (DI) BAWAH, JAUH, } \\
\text { DEKAT, SEBELAH, } \\
\text { DALAM }\end{array}$ \\
\hline Konsep logis & $\begin{array}{l}\text { TIDAK, MUNGKIN, } \\
\text { DAPAT, KARENA, } \\
\text { JIKA }\end{array}$ \\
\hline $\begin{array}{l}\text { Augmentor, } \\
\text { intensifier }\end{array}$ & SANGAT, LEBIH \\
\hline Kesamaan & SEPERTI \\
\hline
\end{tabular}

(Sumber: Goddard, 2006 dalam Mulyadi, 2016)

Pada penjelasan komponen semantik pada verba psikologi, tidak semua eksponen dapat digunakan, kecuali eksponen-eksponen yang dapat menerangkan wilayah verba psikologi. Pada kajian MSA, verba psikologi merupakan bagian dari predikat mental dan bagian-bagiannya diturunkan dari sejumlah eksponen (PIKIR, TAHU, INGIN, RASA, LIHAT, DENGAR) dan sebagainya. 


\section{Polisemi Takkomposisi}

Polisemi bukan merupakan istilah yang baru dalam kajian semantik (Goddard, 1996: 29; Sutjiati Beratha, 1998: 4). Polisemi takkomposisi menurut MSA merupakan bentuk leksikon tunggal yang dapat mengekspresikan dua makna asali yang berbeda dan tidak ada hubungan komposisi antara satu eksponen dengan eksponen lainnya karena eksponen tersebut memiliki kerangka gramatikal yang berbeda (Wierzbicka, 1996c: 27-29).

Pada tingkatan yang sederhana, eksponen dari makna asali yang sama mungkin akan menjadi polisemi dengan cara yang berbeda pada bahasa yang berbeda pula. Sebagai contoh, menurut Goddard (1996: 29), kata makuringanyi dalam bahasa Yankunytjatjara berarti 'ingin' dan di dalam bahasa Inggris dapat diberi arti like, be fond of, dan need, padahal ranah penggunaannya tidak berhubungan dengan ranah want dalam bahasa Inggris.

Goddard lebih lanjut menyatakan bahwa ada dua jenis hubungan takkomposisi, yakni hubungan yang menyerupai (entailmeny like relationship), seperti melakukan/terjadi; dan hubungan implikasi (implicational relationship), seperti merasakan/terjadi. Perhatikan contoh berikut:

(1) X melakukan sesuatu pada Y

Sesuatu terjadi pada Y

(2) Jika X merasakan sesuatu

Maka sesuatu terjadi pada X

Perbedaan sintaksis yang dapat diketahui dari verba melakukan dan terjadi pada contoh (1) di atas ialah bahwa melakukan memerlukan dua argumen, sedangkan terjadi hanya membutuhkan satu argumen. Hubungan implikasi terjadi pada verba terjadi dan merasakan, misalnya, apabila X merasakan sesuatu, maka sesuatu terjadi pada $\mathrm{X}$.

\section{Sintaksis Universal}

Sintaksis universal yang dikembangkan oleh Wierzbicka pada akhir tahun 1980-an (Goddard, 1996: 24) merupakan perluasan dari sistem makna asali. Wierzbicka (1996: 171) menyatakan bahwa makna memiliki struktur yang sangat kompleks, dan tidak hanya dibentuk dari elemen sederhana, seperti seseorang, ingin, tahu, tetapi dari komponen berstruktur kompleks. Sintaksis universal terdiri atas kombinasi leksikon butir makna asali universal yang membentuk proposisi sederhana sesuai dengan perangkat morfosintaksis bahasa yang bersangkutan. Misalnya, ingin akan memiliki kaidah universal tertentu dalam konteks: Saya ingin melakukan ini.

Unit dasar sintaksis universal dapat disamakan dengan sebuah klausa yang dibentuk oleh substantif, predikat, dan beberapa elemen tambahan yang diperlukan oleh predikatnya. Kombinasi elemen-elemen ini akan membentuk sintaksis universal yang, menurut teori MSA, disebut kalimat kanonis (canonical sentence), yaitu konteks tempat leksikon asali diperkirakan muncul secara universal (Sutjiati Beratha, 1998: 5).

Dalam merumuskan struktur semantis sebuah bahasa, teori MSA menggunakan sistem parafrase. Menurut Wierzbicka (1996) dalam 
Sutjiati Beratha (1998:249), parafrase harus mengikuti kaidah-kaidah berikut:

1. Parafrase harus menggunakan kombinasi sejumlah makna asali yang telah diusulkan oleh Wierzbicka. Kombinasi sejumlah makna asali diperlukan terkait dengan klaim dari teori MSA, yaitu suatu bentuk tidak dapat diuraikan hanya dengan memakai satu makna asali.

2. Parafrase dapat pula dilakukan dengan memakai unsur yang merupakan kekhasan suatu bahasa. Hal ini dapat dilakukan dengan menggabungkan unsur-unsur yang merupakan keunikan bahasa itu sendiri untuk menguraikan makna.

3. Kalimat parafrase harus mengikuti kaidah sintaksis bahasa yang dipakai untuk memparafrase.

4. Parafrase selalu menggunakan bahasa yang sederhana.

5. Kalimat parafrase kadang-kadang memerlukan indentasi dan spasi khusus.

\section{METODE PENELITIAN}

Penelitian ini menggunakan penelitian deskriptif kualitatif. Data penelitian berupa kalimat yang didalamnya terdapat verba psikologis (predikat mental) yang bersumber dari Bahasa Mandailing. Instrumen penelitian ini adalah peneliti sendiri dengan memanfaatkan pengetahuan tentang seperangkat konsep dan teori, kemampuan menginterpretasikan kata-kata yang berupa verba psikologi.

Kemudian data dianalisis dengan menggunakan metode agih yaitu untuk 196 mengidentifikasi butir-butir leksikal yang secara intuitif tergolong verba psikologi. Hasil analisis data disajikan dengan metode informal dengan merealisasikan dalam penggunaan kata-kata atau kalimat yang dikembangkan secara deduktif dan induktif.

\section{PEMBAHASAN}

\section{Struktur Semantis Verba Psikologi Bahasa} Mandailing

Struktur semantis adalah jaringan relasi semantis di antara kata-kata dalam sistem leksikon suatu bahasa. Struktur semantis sebuah kata dapat diungkapkan jika maknanya dibandingkan dengan makna kata-kata lain yang dirasakan berhubungan' Jika perbandingannya teiat, ada dua kemungkinan yang ditemukan : struktur semantisnya memiliki kesamaan atau sebaliknya (Mulyadi, 2000: 43).

Kelas verba psikologi (keadaan) BM pada dasarnya tidak berbeda dengan BI bersifat statis karena penunjukan waktunya tidak memungkinkan diperluas. Indikasinya adalah verba psikologi (keadaan) tidak menerima perfektif dan punctual tidak relevan pada verba psikologi (keadaan) karena tidak ada peralihan tindakan diantara partisipan. Sebagai rujukan dalam menguraikan verba psikologi dalam BM, berikut ini dirumuskan klasifikasinya:

Kel I:

Subjek - Trans. V - Objek Sebab

Pengalam

Kel II:

Subjek - Trans. V - Objek Pengalam

Sebab 


\section{(1) Halai parcaya tona $i$}

Mereka percaya pesan itu

(2) Halai lagi parcaya tona $i$

Mereka sedang percaya pesan itu

Kalimat pada data (1) berterima secara semantis dalam BM. Hal itu didasarkan pada fakta bahwa kata 'parcaya' menunjukkan makna statis dan penunjukan waktunya tidak perlu diperluas. Pada data (2) secara semantis tidak berterima sebab mengalami perluasan penunjukan waktu dengan penambahan kata 'sedang' 'lagi'.

Struktur semantis verba keadaan dibentuk elemen yang berbeda. Makna verba kognisi dibentuk polisemi MEMIKIRKAN/MENGATAKAN (seperti mempercayai 'mamparcayai') dan MEMIKIRKAN/TERJADI (seperti menduga 'manduga', mengangankan 'mangangankon', menghayal 'manghayal', melamun 'malamun'). Dalam struktur kognitif terdapat dua jenis peristiwa : masa lampau (mamparcayai, malamun, murnung) dan masa mendatang (manduga, mangangankon, manghayal).

\section{(3) Halai malamun maligi gadis $i$}

Mereka melamun melihat gadis itu

Komponen semantis 'malamun' dalam BM adalah menerangkan ketika terputusnya pikiran seseorang dengan lingkungan sekitarnya, di mana kontak seseorang menjadi kabur digantikan oleh khayalan. Yang menjadi subjek pengalam pada data (3) adalah orang ketiga jamak 'Mereka' 'halai'. Adapun struktur semantisnya diformulasikan sebagai berikut:

\section{Malamun}

$\mathrm{X}$ memikirkan sesuatu tentang Y

$\mathrm{X}$ berpikir seperti ini :

Aku ingin: sesuatu yang baik terjadi

Aku tahu: ini tidak mungkin terjadi

$\mathrm{X}$ memikirkan sesuatu seperti ini

(4) Andi mangangankon dapot daganak kembar Andi mengangankan dapat anak-anak yang kembar.

Komponen semantis 'mangangankon' adalah aktifitas berfikir dalam membayangkan seseorang atau mencita-citakan sesuatu yang akan terjadi. Data (4) 'Andi' sebagai subjek pengalamnya. Dan struktur semantisnya dapat dirumuskan sebagai berikut:

\section{Mangangankon}

$\mathrm{X}$ memikirkan sesuatu tentang $\mathrm{Y}$

$\mathrm{X}$ berpikir seperti ini :

Aku ingin : sesuatu yang baik terjadi

Aku tahu : ini tidak mungkin terjadi

$\mathrm{X}$ memikirkan sesuatu seperti ini.

Struktur semantis verba pengetahuan dibentuk oleh MENGETAHUI/ MENGATAKAN dan anggotanya meliputi mengerti 'mangarti', memahami 'Pohom', mengenal 'mamboto', ingat 'ingot', lupa 'lupa'.

\section{Halai mamboto kajadian $i$}

Mereka mengetahui kejadian itu

Ingot ko dope sanga ise do panakko nai Masih ingat kau siapa malingnya.

Komponen semantis 'mamboto' kemampuan menyatakan suatu tindakan, keberadaan, pengalaman atau pengertian 
dinamis lainnya, ringkasnya 'mamboto' mensyaratkan kemampuan untuk mengungkapkan sesuatu atau seseorang. Subjek pengalam pada kalimat (5) adalah 'mereka' 'halai'. Pada data (6) Subjek pengalamnya adalah orang kedua tunggal 'kamu' ' $k o$ '. Memiliki komponen semantis 'ingot' adalah kemampuan mengatakan sesuatu yang telah terjadi yang merupakan bagian dari sesuatu. Struktur semantisnya dapat diformulasikan sebagai berikut:

Mamboto

$\mathrm{X}$ mengetahui sesuatu tentang $\mathrm{Y}$

Jika $\mathrm{X}$ dapat mengatakan semua bagian dari Y

$\mathrm{X}$ mengetahui sesuatu tentang $\mathrm{Y}$ seperti ini

Ingot

$\mathrm{X}$ tidak mengetahui sesuatu tentang $\mathrm{Y}$

Jika $\mathrm{X}$ tidak dapat mengatakan semua tentang $\mathrm{Y}$

$\mathrm{X}$ mengetahui sesuatu tentang $\mathrm{Y}$ seperti ini

Makna verba emosi dibentuk dari turunan MERASAKAN dan makna ini berpolisemi dengan MEMIKIRKAN. Alasannya bahwa orang yang sedang merasakan emosi tertentu artinya ia sedang mempunyai pikiran tertentu tentang sesuatu. Jenis peristiwa dalam pikiran berorientasi pada (1) masa mendatang seperti takut 'mabiar', marah 'marah', lega 'lopas', dan kecewa 'goyak'. (2) masa kini seperti kagum 'heran', kaget 'tarsonggot', gembira 'sonang', dan bangga 'Jop'dan (3) masa lampau, seperti sedih 'marsak', malu 'maila', bingung 'poning', dan bimbang 'poning'.
(5) Juni mabiar ulok

Juni takut ular

(6) Juni mambiar-biari ulok

Juni menakuti ular

Pada data (7) 'Juni' adalah subjek pengalam, sementara pada data (8) 'Juni' menjadi objek pengalam. Komponen semantisnya adalah merasa gentar (ngeri) menghadapi sesuatu yang dianggap mendatangkan bencana terhadap sesuatu atau seseorang. Struktur semantisnya direpresentasikan di bawah ini.

\section{Mabiar}

$\mathrm{X}$ merasakan sesuatu seperti ini:

Sesuatu yang buruk terjadi

$\mathrm{X}$ tidak menginginkan ini

Setelah ini, X memikirkan sesuatu seperti ini:

$\mathrm{X}$ tahu sekarang: ini akan terjadi

Karena ini, X merasakan sesuatu yang buruk

(7) Omak manyolop tu si butet mama marah kepada si gadis

(8) Omak dipanyolop si butet

mamak dimarahi si gadis

Pada data berikut ini (9) subjek pengalam adalah mama 'omak', dan pada data (10) 'omak' tidak lagi berkedudukan sebagai subjek pengalam tetapi berubah menjadi objek pengalam. Komponen semantis 'manyolop' adalah merupakan keadaan seseorang yang kondisinya tidak senang karena dihina atau diperlakukan tidak sepantasnya. Dan struktur semantisnya dapat diformulasikan sebagai berikut: 


\section{Manyolop}

$\mathrm{X}$ merasakan sesuatu seperti ini:

Sesuatu yang buruk akan terjadi

Lalu X tidak menginginkan ini

Setelah ini, X memikirkan sesuatu seperti ini:

Karena ini, X merasakan sesuatu yang buruk

Namun untuk melihat letak perbedaan verba ini harus dieksplorasi dengan elemen yang membentuknya. Verba 'marah' 'manyolop' dihasilkan dari kombinasi antara TERJADI dan INGIN. Lihat pada ilustrasi berikut ini:

(9) Sesuatu yang buruk dapat terjadi

Aku tidak ingin terjadi

Karena pada dasarnya munculnya kemarahan seseorang memiliki keterkaitan dengan peristiwa yang buruk yang terjadi pada pengalam, pada (11).

Makna verba persepsi dibentuk MELIHAT berpolisemi dengn MERASAKAN (seperti memandang 'mamandang' dan menatap 'manatap'), MELIHAT berpolisemi dengan MENGETAHUI (seperti memeriksa 'mamareso', meninjau 'mancek'), MELIHAT yang berpolisemi dengan MEMIKIRKAN (seperti menonton 'manonton' dan mengawasi 'mangawasi'), dan MELIHAT berpolisemi dengan MENGATAKAN (seperti menengok 'maligi', melirik 'manyirik' dan melotot 'bolnang').

(10) Butet manyirik lembar ujian ni donganna gadis melirik lembar ujian kawannya.

(11) Butet disirik nauli bulung di kampung na
Gadis dilirik pemuda setempat di kampungnya

Data (12) 'Butet' berkedudukan sebagai subjek pengalam. Namun berbeda pada data (13) 'Butet' berkedudukan sebagai objek pengalam. Komponen semantisnya 'manyirik' adalah memuat komponen pengetahuan atau sederhananya melihat dengan tajam ke arah kanan dan kiri. Maka struktur semantisnya diformulasikan dibawah ini:

\section{Manyirik}

Selama beberapa waktu, X melihat Y

Jika X merasakan sesuatu

Karena $X$ ingin mengetahui sesuatu

$\mathrm{X}$ dapat melihat Y seperti ini

(12) Dikot manatap anak na dohot ibo

Dikot menatap anaknya dengan iba

(13) Halai marsitatapan

Mereka saling bertatapan

Komponen semantis 'manatap' merupakan memperhatikan objek, biasanya dalam jarak dekat, dengan saksama dan durasi yang agak panjang. Data (14) menunjukkan 'Dikot' sebagai subjek pengalam, sementara pada data (15) menunjukkan bahwa 'Mereka' 'Halai' merupakan objek pengalam. Struktur semantisnya diformulasikan sebagai berikut:

\section{Manatap}

X Melihat Y dari dekat selama beberapa waktu

Karena X merasakan sesuatu

Bukan karena $\mathrm{X}$ ingin mengetahui sesuatu

X melihat Y Seperti ini keterampilan membaca harus ditingkatkan.

\section{PENUTUP}


Berdasarkan hasil analisis dengan menggunakan teknik analisis prafrase, pemetaan bahasa alamiah dengan data pendukung Verba psikologi (keadaan) dalam BM memiliki verba kognisi, pengetahuan, emosi dan persepsi. Makna verba kognisi MEMIKIRKAN berpolisemi dengan MENGATAKAN dan MEMIKIRKAN berpolisemi dengan TERJADI, makna verba pengetahuan diturunkan dari MENGETAHUI berpolisemi dengan MENGATAKAN, makan verba emosi diturunkan dari MERASAKAN berpolisemi MEMIKIRKAN, makna verba persepsi dibentuk dari MELIHAT berpolisemi dengan MERASAKAN, MELIHAT berpolisemi dengan MENGETAHUI, MELIHAT berpolisemi dengan MENGATAKAN, MELIHAT borpolisemi dengan MEMIKIRKAN.

Struktur semantis verba psikologi (keadaan) yang menjadi fokus kajian ini adalah verba kognisi (melamun 'malamun', mengangankan 'mangangankon'), verba pengetahuan (mengetahui 'mamboto', mengingat 'ingot'), verba emosi (takut 'mabiar', marah 'manyolop'), verba persepsi (melirik 'manyirik', menatap 'manatap').

\section{DAFTAR PUSTAKA}

Broukhuis. (2008). "The Subject of Causative Object Experiencer Verbs". [Dikutip 10 Desember 2019] Tersedia dari: http://www.fdlww.uvt.nl/ broekhui/publicatie s/object_experiencer_psych_verbs.doc.pdf.

Droge, A. (2014). "Structuring the Argument Multidisciplinary Research on Verb Argument
Structure". Language Faculty and Beyond. Amsterdam: Jhon Benjamins

Goddard, C. (1996). "Building a Universal Semantic Metalanguage: the Semantic Theory of Anna Wierzbicka”. Goddard (Convenor). 1996. "Cross-Linguistic Syntax from Semantik Point of View (NSM Approach)". Australia: The Australian National University

Luis, J, C. (2015). "Causativity and psychological verbs in Spanish". 110-130 doi: 10.1075/ivitra.9.06cif [dikutip 12 Desember 2019] tersedia dari: https://www.researchgate.net/publication/300 227729_Causativity_and_psychological_verb s_in_Spanish.pdf

Mulyadi. (2000). "Struktur Semantis Verba Bahasa Indonesia". [Dikutip 31 Desember 2019] tersedia

https://www.researchgate.net/publication/323

279597_STRUKTUR_SEMANTIS_VERBA _BAHASA_INDONESIA.pdf

Mulyadi. (2016). "Verba Emosi Statif Dalam Bahasa Melayu Asahan". Doi: 10.13140/RG.2.1.4646.1042. [dikutip 12 Desember 2019] tersedia dari https://www.researchgate.net/publication/303 812820_VERBA_EMOSI_STATIF_DALAM _BAHASA_MELAYU_ASAHAN.pdf

Rowzdowska, Ena. (2016). "Psychological Verbs And Psychological Adjectives". Doi: 10.1002/9781118358733 [Dikutip 8 Desember 2019] tersedia dari https://onlinelibrary.wiley.com/doi/abs/10.10 02/9781118358733.wbsyncom040.pdf

Sutjiati Beratha, N.L. (1998). "Materi Kajian Linguistik Kebudayaan". Linguistika, Edisi Kesembilan, September 1998, 41-45. Denpasar: Program Magister (S2) Linguistik, Universitas Udayana.

Widani, Ni. (2017). "Makna Mengambil Bahasa Bali": Pendekatan Metabahasa Semantik Alami (MSA). RETORIKA: Jurnal Ilmu Bahasa. 2. 127. 10.22225/jr.2.1.53.127-141.

Wierzbicka, A. (1996). "The Syntax of Universal Semantic Primitives". Dalam C. Goddard (ed). 1996. Cross-Linguistic Syntax from a Semantic Point of View (NSM Approach), 623. Canberra: Australian National University. 